\title{
RANCANG BANGUN SISTEM INFORMASI FORUM ALUMNI STUDI KASUS DI TEKNIK INFORMATIKA POLINEMA MALANG
}

\author{
Yogik Yanuar' ${ }^{1}$, Deddy Kusbianto Purwoko Aji ${ }^{2}$ \\ ${ }^{1}$ Teknik Informatika, Teknologi Informasi, Politeknik Negeri Malang \\ ${ }^{1}$ rpl.yogikyanuar@gmail.com, ${ }^{2}$ deddy_kusbianto@polinema.ac.id
}

\begin{abstract}
Abstrak
Pengolahan data alumni di Politeknik Negeri Malang masih belum ada, sehingga bagi para alumni yang telah lulus masa studinya akan lepas dari kampus. Tetapi seharusnya para mahsiswa yang telah lulus harusnys bisa saling berkomunikasi baik pada sesama alumni maupun pada pihak kampus.

Oleh karena itu, perlu di buat sebuah web yang bisa di akses di manapun dan kapanpun, agar para alumni yang telah lulus dapat saling mengetahui keadaan, dan berita kampus. Maka di buatlah web ini yang menggunakan bahasa PHP, MySQL, HTML, CSS, JavaScript, dan Boostrap. Sistem ini juga telah diuji coba oleh beberapa user dan hasilnya, setiap user dapat mengolah data inventaris dengan mudah dan cepat.
\end{abstract}

Kata Kunci: Website, Forum, Alumni, Teknik Informatika.

\section{Pendahuluan}

Sistem Informasi amat sangat penting terhadap persaingan duniapendidikan pada saat ini. Apalagi kita hidup di era teknologi informasi yangmempunyai karakteristik yang begitu cepat dalam perkembangannya, hari inidunia berubah dengan cepatnya dibandingkan dengan era sebelumnya. Dalamdunia pendidikan perubahan dunia yang begitu cepat sangat dibutuhkan suatupengumpulan dan proses informasi yang merupakan dasar yang paling esensial.Teknologi informasi mempunyai pengaruh besar dalam berbagai aspekkehidupan masyarakat karena sudah merupakan bagian dari kehidupanmasyarakat. Dunia pendidikan, pemerintahan, bisnis dan usaha, sampai kesehatandan kebutuhan harian masyarakat selalu membutuhkan keberadaan informasi.ransaksi-transaksi yang berbasis teknologi informasi berkembang sejalan denganlaju pertumbuhan penggunaan internet.Salah satu kampus yang memanfaatkan internet yaitu Teknik Informatika Polinema Malang yang menggunakan internet sebagai media yang dapat membantu dalammemberikan informasi, baik untuk lingkungan diluar kampus maupun untuklingkungan di dalam kampus itu sendiri. Teknik Informatika Polinema Malang merupakankampus menengah pertama yang berada dibawah naungan Departemen Pendidikan Nasional yang berusaha untuk meningkatkan kualitas pendidikan dan kemampuansiswanya. Di Teknik Informatika Polinema Malang terdapat sebuah majalah dinding (mading)yang berfungsi sebagai media penyimpanan informasi kampus, namun belum terdapat media untuk penyimpanan informasi alumni. Pengolahan data alumni diTeknik Informatika Polinema Malang belum mendapat perhatian yang lebih dari pihak kampus,sehingga penyimpanan datanya masih dalam bentuk kumpulan berkas-berkas yang disimpan didalam sebuah lemari. Karena belum adanya pengelolaan dataalumni di Teknik Informatika Polinema Malang, sehingga hal ini menyulitkan alumni ketikaberinteraksi dengan alumni lainnya ataupun dengan pihak kampus.

\section{Landasan Teori}

\subsection{Sistem Pendukung Keputusan}

Sistem pendukung keputusan (decision support systems disingkat DSS) adalah bagian dari sistem informasi berbasis komputer (termasuk sistem berbasis pengetahuan (manajemen pengetahuan) yang dipakai untuk mendukung keputusan dalam suatu organisasi atau perusahaan. Dapat juga dikatakan sebagai sistem komputer yang mengolah data menjadi informasi untuk mengambil keputusan dari masalah semi-terstruktur yang spesifik.

Sistem pendukung pengambilan keputusan kelompok (DSS) adalah sistem berbasis komputer yang interaktif, yang membantu pengambil keputusan dalam menggunakan data dan model untuk menyelesaikan masalah yang tidak terstruktur. Sistem pendukung ini membantu pengambilan keputusan manajemen dengan menggabungkan data, modelmodel dan alat-alat analisis yang komplek, serta perangkat lunak yang akrab dengan tampilan pengguna ke dalam satu sistem yang memiliki kekuatan besar (powerful) yang dapat mendukung pengambilan keputusan yang semi atau tidak terstruktur. DSS menyajikan kepada pengguna satu perangkat alat yang fleksibel dan memiliki kemampuan tinggi untuk analisis data penting. 
Dengan kata lain, DSS menggabungkan sumber daya intelektual seorang individu dengan kemampuan komputer dalam rangka meningkatkan kualitas pengambilan keputusan. DSS diartikan sebagai tambahan bagi para pengambil keputusan, untuk memperluas kapabilitas, namun tidak untuk menggantikan pertimbangan manajemen dalam pengambilan keputusannya.

Penyusunan sebuah model keputusan merupakan suatu cara untuk mengembangkan hubunganhubungan logis yang mendasari persoalan keputusan kedalam suatu bentuk model matematis, yang mencerminkan hubungan di antara faktor-faktor yang terlibat. Proses pengambilan keputusan terdiri dari empat fase, yaitu :

TOPSIS (Technique For Others Reference by Similarity to Ideal Solution) adalah salah satu metode pengambilan keputusan multikriteria yang pertama kali diperkenalkan oleh Yoon dan Hwang pada tahun 1981. TOPSIS menggunakan prinsip bahwa alternatif yang terpilih harus mempunyai jarak terdekat dari solusi ideal positif dan terjauh dari solusi ideal negatif dari sudut pandang geometris dengan menggunakan jarak Euclidean untuk menentukan kedekatan relatif dari suatu alternatif dengan solusi optimal. Solusi ideal positif didefinisikan sebagai jumlah dari seluruh nilai terbaik yang dapat dicapai untuk setiap atribut, sedangkan solusi negatif-ideal terdiri dari seluruh nilai terburuk yang dicapai untuk setiap atribut.

TOPSIS mempertimbangkan keduanya, jarak terhadap solusi ideal positif dan jarak terhadap solusi ideal negatif dengan mengambil kedekatan relatif terhadap solusi ideal positif. Berdasarkan perbandingan terhadap jarak relatifnya, susunan prioritas alternatif bisa dicapai. Metode ini banyak digunakan untuk menyelesaikan pengambilan keputusan secara praktis. Hal ini disebabkan konsepnya sederhana dan mudah dipahami, komputasinya efisien, dan memiliki kemampuan mengukur kinerja relatif dari alternatif-alternatif keputusan.

\section{Metodologi Penelitian}

Metode penelitian dibagi atas lima tahap. Yakni Analisis, desain, implementasi, pengujian, dan dokumentasi.

\subsection{Studi Kelayakan (Intelligence)}

Penentuansasaran, pencarian prosedur, pengumpulan data, identifikasi masalah, identifikasi kepemilikan masalah, klasifikasi masalah, hingga akhirnya terbentuk sebuah pernyataan masalah.

\subsection{Perancangan (Design)}

Model yang akan digunakan serta kriteria-kriteria yang mungkin ditentukan. Setelah itu akan dicari alternatif model yang bias menyelesaikan permasalahan tersebut. Kemudian menentukan model yang akan digunakan dalam system. Dalam tahapan ini, ditentukan arsitektur dari system dengan merancang ERD (Entity Relationship Diagram), database, DFD (Data Flow Diagram), dan perancangan antarmuka.

a. Perancangan Sistem (Use Case)

b. Implementasi Tahapimplementasisistem (system implementation)
tahapanuntukmeletakkansystemsupayasiapdio perasikan.Padatahapaniniterdapatbeberapaakti vitas, antaralain :

c. PemrogramandanPengetesan Program

d. Instalasi Perangkat Keras dan Lunak

e. PengujianSistem

\section{Analisis dan Perancangan}

\subsection{Analisis}

Sistem alumni pada Politeknik Negeri Malang di Teknik Informatika tidak ada sama sekali di karenakan jika mereka lulus berarti mereka telah lepas dan tak ada hubungan lagi dengan pihak kampus ataupun sesama alumni TI Politeknik Negeri Malang. Sistem ini menggunakan web untuk menjalankan kebutuhan untuk semua alumni.

Dalam prosesnya mahasiswa alumni yang sudah tercatat bisa langsung login / bisa registrasi ulang untuk dapat melalukan aktivitas dan mengoperasikan dengan baik dan benar. Kemudian mahasiswa alumni yang telah terdaftar dapat melihat berita mencari teman dan info tentang kampus serta mengisi buku tamu. Cara yang seperti ini sangat mempermudah alumni untuk bisa berinteraksi dengan baik dengan pihak kampus dan sesama alumni.

\subsection{Pemecahan Masalah}

\section{Deskripsi Sistem}

Sistem Pendukung Keputusan Penilaian Proses Belajar Mengajar di Politeknik Negeri Malang Program Studi Teknik Informatika dengan Metode TOPSIS (Technique for Order Preference by Similarity to Ideal Solution) merupakan sistem yang digunakan untuk mendapatkan berita terbaru bagi para alumni, baik dari alumni yang lain, admin maupun dari kampus.

Setiap alumni akan diberikan kebebasan untuk dapat melakukan hal baik pada sistem ini, dengan banyak kemudahan yang di dapat juga bisa berinteraksi dengan baik.

Pada sisi admin, admin dapat melakukan manajemen data seperti menambah, menghapus, mengubah isi dari sistem ini. Selain itu admin memperoleh banayk berita yang di inputkan oleh para alumni. Pada sistem ini penghitungannya menggunakan metode TOPSIS. 


\section{Spesifikasi Sistem}

Spesifikasi kebutuhan sistem ini meliputi spesifikasi pengguna, spesifikasi perangkat lunak, dan spesifikasi perangkat keras.

\section{Spesifikasi Kebutuhan Pengguna}

Sistem Pendukung Keputusan Forum Alumni Teknik Informatika di Politeknik Negeri Malang dengan Metode TOPSIS (Technique for Order Preference by Similarity to Ideal Solution) merupakan sistem yang digunakan untuk memberi informasi kepada para alumni Politeknik Negeri Malang khususnya Alumni Teknik Informatika.

Dalam sistem ini, kegiatan yang bisa dilakukan antara lain :
a. Alumni melakukan registrasi data mereka.
b. Menambah berita terbaru tanpa batas waktu.
c. Mencari alumni yang telah lulus.
d. Meninggalkan pesan pada buku tamu

\section{Spesifikasi Kebutuhan Perangkat Lunak}

Berikut adalah spesifikasi perangkat lunak yang digunakan dalam pembuatan Forum Alumni di Politeknik Negeri Malang Program Studi Teknik Informatika dengan metode TOPSIS (Technique for Order Preference by Similarity to Ideal Solution).

\section{Implementasi}

\subsection{Instalasi Software}

Pada Instalasi software untuk aplikasi Forum Alumni Teknik Informatika Politeknik Negeri Malang ini meliputi kebutuhan server dengan mengaktifkan web server.

Untuk dapat mengakses halaman website yang dibuat adalah dengan mengetikkan alamat url yang sudah dicopykan kedalam folder htdoc. Kemudian website yang dibuat dapat diakses dengan menggunakan kata localhost. Localhost adalah nama standar yang diberikan sebagai alamat loopback network interface. Localhost selalu menerjemahkan loopback ip address 127.0.0.1.

Localhost digunakan untuk mengantarkan web browser pada HTTP server yang terinstall di komputer lokal. Alamat http://localhost akan menampilkan website lokal pada komputer yang bersangkutan. Berikut adalah alamat yang harus diketikkan didalam address bar pada browser : http://localhost/alumniTI/.

\subsection{Pembuatan aplikasi}

\subsubsection{Membuat koneksi ke database}

Database yang dibuat menggunakan MySQL yang telah terinstal pada web server

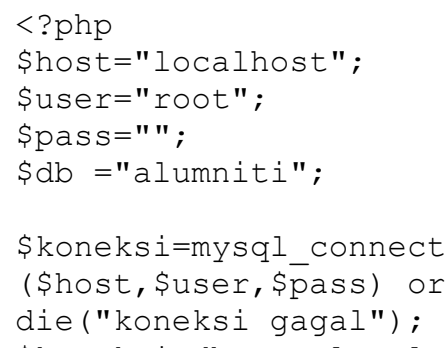

\subsubsection{Membuat program aplikasi}

Sistem Forum Alumni Teknik Informatika Politeknik Negeri Malang terdapat 2 user interface yaitu admin ( bagian kepegawaian ) dan mahasiswa. Pembuatannya menggunakan bahasa pemrograman PHP dan dalam pembuatan tampilan menggunakan twitter bootstrap. Modul yang dibuat pada aplikasi ini adalah:

a. Modul login pada halaman admin dan mahasiswa.

b. Modul registrasi halaman alumni.

c. Modul input berita baru pada halaman admin dan mahasiswa.

d. Modul cari alumni pada halaman alumni.

Modul input buku tamu pada halaman alumni.

\section{Pengujian dan Pembahasan}

\subsection{Tujuan Uji Coba}

Tujuan dari ujicoba ini dilakukan untuk mengetahui fungsi - fungsi yang berjalan pada aplikasi. Selain itu untuk mengukur tingkat keberhasilan dalam pembuatan aplikasi.

\subsection{Proses Uji Coba}

Halaman User ( Alumni )

1.Login. Sebelum melakukan aktivitas dalam forum, harus melakukan login terlebih dahulu menggunakan username dan password

2.Halaman utama user ( Alumni ). Alumni dapat melihat berita terbaru dari halaman ini. tiap alumni dapat melihat juga dapat melakukan input berita pada halaman selanjutnya.

3.Halaman Data Alumni. Pada halaman ini, semua para alumni dapat mencari alumni yang lain berdasarkan tahun lulus.

4.Buku Tamu. Pada halaman ini para alumni terdaftar dapat meninggalkan pesan-pesan yang di inginkan.

\subsection{Analisis Hasil Uji Coba}

Dari pengujian yang dilakukan maka dapat disimpulkan bahwa setiap user (alumni) dapat melakukan input dan melihat tampilan pada halaman tersebut, sehingga setiap alumni yang telah melakukan 
aktivitas di dalamnya dapat berinteraksi secara tidak langsung terhadap alumni lain.

\section{Kesimpulan dan Saran}

\subsection{Kesimpulan}

Dari hasil pengujian yang telah dilakukan, dapat ditarik kesimpulan sebagai berikut.

1. Dengan menggunakan forum alumni ini, mampu membangun sebuah aplikasi forum yang baik dan dibuktikan dengan tingkat kepuasan pengguna yaitu sebesar $70 \%$ pada ke inovatifan.

2. Melalui Forum Alumni ini, pengembangan data pada data-data alumni Di Politeknik Negeri Malang bertambah, dibuktikan dengan tingkat kepuasan sebesar $80 \%$ pada pengembangan data tersebut.

\subsection{Saran}

Forum Alumni Teknik Informatika Politeknik Negeri Malang dengan Metode TOPSIS (Technique for Order Preference by Similarity to Ideal Solution) untuk pengembangannya diharapkan :
1. Sistem ini dapat dikembangkan dengan fungsi fungsi yang lebih baik sesuai dengan perkembangan teknologi yang ada sehingga dapat terus dimanfaatkan di Politeknik Negeri Malang.

2. Sosialisasi pada pengguna sangat dibutuhkan sehinggga sistem ini dapat dipergunakan dengan baik oleh admin maupun user.

\section{Daftar Pustaka:}

Suryadi dan Ramdani (1998). Sifat sifat Sistem Pengambilan Keputusan (SPK).

Yoon dan Hwang (1981). Definisi dan prosedur TOPSIS (Technique For Others Reference by Similarity to Ideal Solution).

Little (1970). Definisi SPK sebagai sekumpulan prosedur berbasis model untuk data pemrosesan dan penilaian guna membantu mengambil keputusan.

Murnawan, Akhmad Fadjar Siddiq. 2012. "Sistem Pendukung Keputusan Menggunakan Metode Technique for Order by Similarity to Ideal Solution (TOPSIS)". Jurnal Sistem Informasi (JSI) Fakultas Ilmu Komputer Universitas Sriwijaya, VOL. 4, NO. 1, April 2012. 